\title{
OPTIMALISASI INFORMASI CITRA T1 W1 POST-CONTRAST DENGAN FAT SATURATION DAN PENGATURAN TIME REPETITION: STUDI PADA PEMERIKSAAN MAGNETIC RESONANCE IMAGING BRAIN DENGAN KASUS TUMOR
}

\section{IMAGE INFORMATION OPTIMIZATION OF T1 WI POST CONTRAST USING FAT SATURATION AND TIME REPETITION SETING: STUDY OF MAGNETIC RESONANCE IMAGING IN BRAIN TUMOR}

\author{
Akhmad Haris Sulistiyadi $^{1)}$, Ari Suwondo ${ }^{2)}$, Sugiyanto ${ }^{3)}$ \\ ${ }^{1,3)}$ Health Polytechnics of Semarang-Indonesia \\ ${ }^{2)}$ Post Graduate Program, Diponegoro University-Indonesia \\ e-mail: haris5757@yahoo.com
}

\begin{abstract}
Background: Fat saturation is an alternative technique to improve image information in T1 WI post contrast MRI of brain tumor. It can increase lesion conspituity by suppressing normal tissue's signal. To optimize image information by using fat saturation, selection of Fat Saturation type and Time Repetition (TR) value are important.

Objectives: to analyze the differences in T1 WI post-contrast image information in MRI of brain tumor in various type of Fat Saturation and TR value.

Methods: Experimental study with factorial design conducted in Telogorejo Hospital-Semarang. Nine combinations (9 groups) of three Fat Saturation types (none, weak, and strong) by three TR values (700 ms, $750 \mathrm{~ms}$, and $800 \mathrm{~ms}$ ) were given to 12 patients of MRI brain tumor. Image informations were assessed by measuring SNR (white matter, gray matter, lesions, surrounding tissue), CNR (white matter- gray matter, white matter-CSF, gray matter-CSF, lesion- surrounding tissue), lesion conspituity, artifacts, and contrast image in general.

Results: The results showed that there were significant differences in SNR of white matter, gray matter, and in surrounding tissue $(p<0.05)$; CNR of white matter-CSF, gray matter-CSF, lesion-tissue surrounding tissue $(p<0.05)$; and lesion conspituity $(p<0.05)$ between groups with no sat fat, weak fat sat, and strong fat sat. There were significant differences in SNR of white matter, gray matter, and surrounding tissue (p $<0.05$ ); and CNR of white matter-CSF, gray matter-CSF, and lesion- surrounding tissue ( $p<0.05)$ between group TR $700 \mathrm{~ms}$, TR $750 \mathrm{~ms}$, and TR $800 \mathrm{~ms}$.

Conclusion: Combination of strong fat saturation and TR $700 \mathrm{~ms}$ can produce the most optimal image information.
\end{abstract}

Keywords: Fat saturation, Time Repetition, MRI Brain Tumor

\section{PENDAHULUAN}

Tumor otak merupakan ancaman yang serius bagi kesehatan. Tumor jenis ini lebih sulit disembuhkan dengan tindakan-tindakan yang biasanya dapat dilakukan pada jenis tumor lain. Pemotongan jaringan secara tuntas untuk memisahkan tumor dari jaringan normal lebih sulit dilakukan dan sangat beresiko. Pemberian terapi radiasi memerlukan dosis yang lebih tinggi dan tidak jarang juga menyebabkan kerusakan pada jaringan normal. Selain itu, beberapa jenis tumor lebih resisten terhadap kemoterapi (American Brain Tumour Association, 2008 dan De Angelis L, 2002). Pada tahun 2001, di Amerika dilaporkan terdapat 17.200 kasus tumor otak dan CNS lainnya. Tumor jenis primer telah membunuh 13.100 orang diantaranya ( Jemal dkk, 2003).

Pencitraan diagnostik diperlukan untuk deteksi dan terapi tumor. Pencitraan diagnosik standar untuk tumor otak adalah Magnetic Resonance Imaging (MRI) dengan media kontras Gadolinium.4 Citra MRI diperlukan untuk memberikan gambaran awal tipe tumor, lokasi, ukuran, karakterisasi, staging, dan struktur di sekitar tumor, perencanaan terapi dan pemantauan hasil terapi. Citra T1WI post contrast memberikan gambaran batasan tumor dan merupakan dasar untuk menentukan Region of Interest (ROI) pada pembuatan citra perfusi (Mehndiratta A, 2011 dan Wahjoeepramono, 2006).

Pada T1 WI, lemak dan tumor yang menyerap media kontras paramagnetik menghasilkan sinyal yang tinggi. Padahal tumor dapat berlokasi di jaringan-jaringan yang mengandung lemak seperti di bone marrow, retro orbita, maupun lokasi-lokasi lainnya sehingga berpotensi menyebabkan gambaran dengan batasan tumor yang kurang jelas (Chysikopoulus HS, 2009)

Salah satu upaya yang dapat dilakukan untuk meningkatkan informasi citra MRI T1 WI post contrast adalah penggunaan teknik fat saturation. Dengan fat saturation, sinyal jaringan normal di sekitar tumor tersupresi sehingga kejelasan tumor dapat meningkat.

Untuk mengaplikasikan fat saturation, diperlukan pengaturan berbagai parameter untuk menghasilkan citra yang optimal. Parameter yang harus disesuaikan pada penggunaan fat saturation adalah pengaturan nilai Time Repetition (TR) dan pemilihan jenis fat saturation yang digunakan. 
Tujuan penelitian ini adalah untuk menganalisis perbedaan informasi citra pada berbagai jenis fat saturation dan nilai Time Repetition, dan mengetahui kombinasi yang paling optimal.

\section{METODE}

Jenis penelitian yang dilakukan adalah eksperimental dengan rancangan faktorial. Populasi studi adalah 12 pasien MRI brain dengan media kontras dengan kasus tumor di RS Telogorejo Semarang dan memenuhi kriteria inklusi.

\section{HASIL}

Tabel 1 menunjukkan bahwa $50 \%$ pasien berjenis kelamin laki-laki dan $50 \%$ pasien bejenis kelamin perempuan Tabel 2 menunjukkan bahwa $58 \%$ pasien termasuk dalam kelompok umur 41-60 tahun, 25\% pasien tergolong dalam kelompok umur $<21$ tahun, dan $17 \%$ pasien tergolong dalam kelompok umur 21-40 tahun.

Kelainan yang ditemukan adalah meningioma (34\%), Low Grade Astrocytoma (17\%), masa ekstra aksial (17\%), Acoustic Neuroma (8\%), Metastase Intra aksial (8\%), Pseudoabses Tuberkuloma (8\%), dan Ependyoma (8\%).

Tabel 4 menunjukkan bahwa SNR tertinggi pada masing-masing objek adalah 32,250 $\pm 1,618$ (white matter), $30,375 \pm 0,250$ (gray matter), 13,825 $\pm 0,250(\mathrm{CSF}), 43,350 \pm$ 0,300 (lesi), dan 33,425 $\pm 1,325$ (jaringan di sekitar lesi). SNR terendah pada masing-masing objek adalah 26,300 $\pm 0,163$ (white matter), 24,325 $\pm 0,263$ (gray matter), 11,450 $\pm 0,170$ (CSF), 38,850 \pm 0,191 (lesi), dan 24,700 $\pm 1,854$ (jaringan di sekitar lesi).

Tabel 5 menunjukkan bahwa secara deskriptif, nilai CNR pada masing-masing kelompok bervariasi. CNR pada white matter-CSF dan gray matter-CSF tertinggi $(18,425 \pm$ $0,263$ dan $16,550 \pm 0,208)$ dihasilkan oleh kelompok tanpa fat saturation dengan TR $800 \mathrm{~ms}$. CNR white matter-CSF terendah $(14,800 \pm 0,337)$ dihasilkan oleh kelompok strong fat saturation dengan TR $800 \mathrm{~ms}$. CNR gray matter-CSF terendah $(12,850 \pm 0,370)$ dihasilkan oleh kelompok strong fat saturation dengan TR $700 \mathrm{~ms}$ CNR white matter-gray matter tertinggi $\quad(2,050 \pm 0,378)$ dihasilkan oleh kelompok tanpa fat saturation dengan TR $700 \mathrm{~ms}$. CNR white matter-gray matter tertinggi $(2,050 \pm 0,378)$ dihasilkan oleh kelompok tanpa fat saturation dengan TR $700 \mathrm{~ms}$ dan terendah dihasilkan oleh kelompok tanpa fat saturation dengan TR 800 ms. CNR lesi dengan jaringan di sekitar lesi yang tertinggi $(15,850 \pm 0,719)$ dihasilkan oleh kelompok strong fat saturation dengan TR $800 \mathrm{~ms}$ sedangkan yang terendah $(8,950 \pm 1,454)$ dihasilkan oleh kelompok tanpa fat saturation dengan TR $700 \mathrm{~ms}$.

Tabel 6 menunjukan bahwa hasil penilaian radiolog terhadap kejelasan lesi bervariasi. Kejelasan lesi tertinggi $(3,00 \pm 0,00)$ dihasilkan oleh kelompok strong fat saturation pada hampir semua nilai TR (700 ms, $750 \mathrm{~ms}$, dam $800 \mathrm{~ms})$. Kejelsan lesi terendah $(2,00 \pm 0,00)$ dihasilkan oleh kelompok tanpa fat saturation dengan TR $700 \mathrm{~ms}$.
Tabel 1. Distribusi Frekuensi Jenis Kelamin

\begin{tabular}{lll}
\hline Jenis Kelamin & Frekuensi & Prosentase \\
\hline Laki-laki & 6 & $50 \%$ \\
Perempuan & 6 & $50 \%$ \\
\hline
\end{tabular}

Tabel 2. Distribusi Frekuensi Umur Pasien

\begin{tabular}{ccc}
\hline Umur & Frekuensi & Prosentase \\
\hline$<21$ tahun & 3 & $25 \%$ \\
$21-40$ tahun & 2 & $17 \%$ \\
$41-60$ tahun & 7 & $58 \%$ \\
\hline
\end{tabular}

Tabel 3. Distribusi Frekuensi Jenis Kelainan

\begin{tabular}{llc}
\hline \multicolumn{1}{c}{ Jenis Kelainan } & $\mathrm{n}$ & $\%$ \\
\hline Meningioma & 4 & $34 \%$ \\
Low grade Astrocytoma & 2 & $17 \%$ \\
Masa ekstra aksial & 2 & $17 \%$ \\
Acoustic Neuroma & 1 & $8 \%$ \\
Metastase Intra aksial & 1 & $8 \%$ \\
Pseudoabses Tuberkuloma & 1 & $8 \%$ \\
Ependyoma & 1 & $8 \%$ \\
\hline
\end{tabular}

Tabel 4. Hasil Analisis Deskriptif terhadap Signal to Noise Ratio Citra T1WI post Contrast dengan Kasus Tumor pada Berbagai Jenis Fat Saturation dan Nilai Time Repetition

\begin{tabular}{lcccc}
\hline \multirow{2}{*}{ Obyek } & \multirow{2}{*}{ TR } & \multicolumn{3}{c}{ Rerata SNR } \\
\cline { 3 - 5 } & & OX & X1 & X2 \\
\hline white & OY & $28,475 \pm 0,1500$ & $27,425 \pm 0,222$ & $26,300 \pm 0,163$ \\
& Y1 & $30,375 \pm 0,1893$ & $28,300 \pm 0,163$ & $27,225 \pm 0,189$ \\
gray & Y2 & $32,250 \pm 1,618$ & $29,525 \pm 0,450$ & $28,275 \pm 0,170$ \\
matter & Y & $26,425 \pm 0,457$ & $25,525 \pm 0,403$ & $24,325 \pm 0,263$ \\
& Y1 & $28,350 \pm 0,129$ & $26,325 \pm 0,126$ & $25,250 \pm 1,349$ \\
CSF & Y2 & $30,375 \pm 0,250$ & $27,650 \pm 0,252$ & $26,350 \pm 1,764$ \\
& OY & $11,325 \pm 0,150$ & $11,200 \pm 0,141$ & $11,450 \pm 0,170$ \\
& Y1 & $12,250 \pm 0,173$ & $12,225 \pm 0,096$ & $12,225 \pm 0,096$ \\
lesi & Y2 & $13,825 \pm 0,250$ & $13,425 \pm 0,320$ & $13,475 \pm 0,170$ \\
& OY & $38,300 \pm 0,163$ & $38,675 \pm 0,386$ & $38,850 \pm 0,191$ \\
& Y1 & $40,500 \pm 0,081$ & $40,450 \pm 0,173$ & $40,550 \pm 0,129$ \\
Jaringan & Y2 & $43,350 \pm 0,300$ & $42,800 \pm 0,115$ & $42,500 \pm 0,432$ \\
di Sekitar & OY & $29,350 \pm 1,340$ & $26,250 \pm 1,215$ & $24,700 \pm 1,854$ \\
Lesi & Y1 & $31,375 \pm 1,024$ & $27,375 \pm 1,486$ & $26,400 \pm 1,390$ \\
& Y2 & $33,425 \pm 1,325$ & $28,950 \pm 0,772$ & $26,650 \pm 0,412$ \\
\hline
\end{tabular}

Keterangan: $0 \mathrm{X}=$ tanpa fat sat, $\mathrm{X} 1=$ weak fat sat, $\mathrm{X} 2=$ strong fat sat, $\mathrm{OY}=\mathrm{TR} 700 \mathrm{~ms}$, $\mathrm{Y} 1=\mathrm{TR} 750 \mathrm{~ms}, \mathrm{Y} 2=\mathrm{TR} 800 \mathrm{~ms}$

Tabel 7 menunjukkan hasil penilaian radiolog terhadap artefak. Hampir pada semua kelompok, radiolog memberikan penilaian 3,00 $\pm 0,000$. Tabel 8 menunjukkan bahwa penilaian radiolog terhadap kontras citra secara umum. Nilai terendah $2,75 \pm 0,50$ dan tertinggi $3,00 \pm 0,000$. 
Tabel 5. Hasil Analisis Deskriptif terhadap Contrast to Noise Ratio Citra T1WI post Contrast dengan Kasus Tumor pada Berbagai Jenis Fat Saturation dan Nilai Time Repetition

\begin{tabular}{lcccc}
\hline \multirow{2}{*}{ Obyek } & \multirow{2}{*}{ TR } & \multicolumn{3}{c}{ Rerata CNR } \\
\cline { 3 - 5 } & & OX & $\mathrm{X} 1$ & $\mathrm{X} 2$ \\
\hline white matter- & OY & $2,050 \pm 0,378$ & $1,900 \pm 0,503$ & $1,975 \pm 0,403$ \\
gray matter & Y1 & $2,025 \pm 0,206$ & $1,875 \pm 0,250$ & $1,975 \pm 0,126$ \\
& Y2 & $1,875 \pm 0,150$ & $1,916 \pm 0,321$ & $1,925 \pm 0,957$ \\
white matter- & OY & $17,150 \pm 0,173$ & $16,225 \pm 0,330$ & $14,825 \pm 0,263$ \\
CSF & Y1 & $18,125 \pm 0,150$ & $16,075 \pm 0,150$ & $15,000 \pm 0,183$ \\
& Y2 & $18,425 \pm 0,263$ & $16,100 \pm 0,668$ & $14,800 \pm 0,337$ \\
gray matter- & OY & $15,125 \pm 0,368$ & $14,325 \pm 0,299$ & $12,850 \pm 0,370$ \\
CSF & Y1 & $16,100 \pm 0,115$ & $14,100 \pm 0,115$ & $13,025 \pm 0,170$ \\
& Y2 & $16,550 \pm 0,208$ & $14,225 \pm 0,450$ & $12,875 \pm 0,359$ \\
lesi-jaringan & OY & $8,950 \pm 1,454$ & $12,425 \pm 1,452$ & $14,150 \pm 1,692$ \\
sekitar & Y1 & $9,125 \pm 0,998$ & $13,075 \pm 1,513$ & $14,150 \pm 1,338$ \\
& Y2 & $9,925 \pm 1,242$ & $13,850 \pm 0,789$ & $15,850 \pm 0,719$ \\
\hline Keteranga & OX & &
\end{tabular}

Keterangan : $0 \mathrm{X}=$ tanpa fat sat, $\mathrm{X} 1=$ weak fat sat, $\mathrm{X} 2=$ strong fat sat, $\mathrm{OY}=\mathrm{TR} 700 \mathrm{~ms}$, $\mathrm{Y} 1=\mathrm{TR} 750 \mathrm{~ms}, \mathrm{Y} 2=\mathrm{TR} 800 \mathrm{~ms}$

Tabel 6. Hasil Analisis Deskriptif terhadap Kejelasan Lesi Citra T1WI post Contrast dengan Kasus Tumor pada Berbagai Jenis Fat Saturation dan Nilai Time Repetition

\begin{tabular}{cccc}
\hline TR & 0X & X1 & X2 \\
\hline 0Y & $2,00 \pm 0,00$ & $2,75 \pm 0,50$ & $3,00 \pm 0,00$ \\
Y1 & $2,25 \pm 0,50$ & $3,00 \pm 0,00$ & $3,00 \pm 0,00$ \\
Y2 & $2,25 \pm 0,50$ & $3,00 \pm 0,00$ & $3,00 \pm 0,00$
\end{tabular}

Keterangan: $0 \mathrm{X}=$ tanpa fat sat, $\mathrm{X} 1=$ weak fat sat, $\mathrm{X} 2=$ strong fat sat, OY=TR $700 \mathrm{~ms}, \mathrm{Y} 1=T R 750 \mathrm{~ms}, \mathrm{Y} 2=\mathrm{TR} 800 \mathrm{~ms}$

Tabel 7 menunjukkan hasil penilaian radiolog terhadap artefak. Hampir pada semua kelompok, radiolog memberikan penilaian 3,00 $\pm 0,000$.

\begin{tabular}{cccc}
\hline TR & 0X & X1 & X2 \\
\hline 0Y & $3,00 \pm 0,000$ & $3,00 \pm 0,000$ & $3,00 \pm 0,000$ \\
Y1 & $2,75 \pm 0,5$ & $3,00 \pm 0,000$ & $3,00 \pm 0,000$ \\
Y2 & $3,00 \pm 0,000$ & $3,00 \pm 0,000$ & $3,00 \pm 0,000$ \\
\hline
\end{tabular}

Keterangan: $0 \mathrm{X}=$ tanpa fat sat, $\mathrm{X} 1=$ weak fat sat, $\mathrm{X} 2=$ strong fat sat, OY=TR $700 \mathrm{~ms}, \mathrm{Y} 1=\mathrm{TR} 750 \mathrm{~ms}, \mathrm{Y} 2=\mathrm{TR} 800 \mathrm{~ms}$

Tabel 8. Hasil Analisis Deskriptif terhadap Kontras Citra Secara Umum Citra T1WI Post Contrast dengan Kasus Tumor pada Berbagai Jenis Fat Saturation dan Nilai Time Repetition

\begin{tabular}{cccc}
\hline TR & 0X & X1 & X2 \\
\hline OY & $2,75 \pm 0,50$ & $2,50 \pm 0,577$ & $2,25 \pm 0,500$ \\
Y1 & $2,75 \pm 0,50$ & $2,50 \pm 0,577$ & $2,50 \pm 0,577$ \\
Y2 & $3,00 \pm 0,000$ & $2,75 \pm 0,500$ & $2,75 \pm 0,500$ \\
\hline
\end{tabular}

Keterangan: $0 \mathrm{X}=$ tanpa fat sat, $\mathrm{X} 1=$ weak fat sat, $\mathrm{X} 2=$ strong fat sat, $0 \mathrm{Y}=\mathrm{TR} 700 \mathrm{~ms}, \mathrm{Y} 1=\mathrm{TR} 750 \mathrm{~ms}, \mathrm{Y} 2=\mathrm{TR} 800 \mathrm{~ms}$
Tabel 9 menunjukkan bahwa terdapat perbedaan bermakna pada CNR white matter-CSF $(\mathrm{p}<0,05)$, gray matter-CSF $(\mathrm{p}<0,05)$, dan lesi-jaringan di sekitar lesi $(\mathrm{p}<0,05)$. Pada CNR white matter-gray matter tidak terdapat perbedaan bermakna $(\mathrm{p}>0,05)$. Pada CNR white matter-CSF, gray matter-CSF, dan lesi-jaringan di sekitar lesi gray matter, terdapat perbedaan bermakna antara kelompok tanpa fat saturation dan weak fat saturation ( $\mathrm{p}<0,05)$, tanpa fat saturation dan strong fat saturation ( $\mathrm{p}<0,05)$, serta antara kelompok weak fat saturation dan strong fat saturation $(\mathrm{p}<$ 0,05 ) pada semua nilai TR. Analisis terhadap kejelasan lesi diawali dengan Uji Kappa untuk mengetahui reliabilitas antar responden. Hasil Uji Kappa ditunjukkan pada tabel 10.

Tabel 9. Hasil Analisis Bivariat Terhadap SNR pada Berbagai Jenis Fat Saturation

\begin{tabular}{|c|c|c|c|c|c|}
\hline \multirow{2}{*}{ CNR } & \multirow{2}{*}{ TR } & \multicolumn{4}{|c|}{ p value } \\
\hline & & 0X-X1-X2 & 0X-X1 & 0X-X2 & X1-X2 \\
\hline White & OY & $0,853^{\mathrm{a}}$ & $0,843^{\mathrm{c}}$ & $0,976^{\mathrm{c}}$ & $0,935^{\mathrm{c}}$ \\
\hline Matter- & Y1 & $0,893^{b}$ & $0,647^{d}$ & $0,877^{d}$ & $0,762^{\mathrm{d}}$ \\
\hline $\begin{array}{c}\text { Gray } \\
\text { Matter }\end{array}$ & $\mathrm{Y} 2$ & $0,853^{\mathrm{a}}$ & $0,843^{\mathrm{c}}$ & $0,976^{\mathrm{c}}$ & $0,935^{\mathrm{c}}$ \\
\hline White & OY & $0,001^{\mathrm{a}}$ & $0,001^{\mathrm{c}}$ & $0,001^{\mathrm{c}}$ & $0,001^{\mathrm{c}}$ \\
\hline Matter- & Y1 & $0,007^{b}$ & $0,017^{d}$ & $0,020^{\mathrm{d}}$ & $0,018^{d}$ \\
\hline CSF & $\mathrm{Y} 2$ & $0,001^{\mathrm{a}}$ & $0,001^{c}$ & $0,001^{\mathrm{c}}$ & $0,001^{\mathrm{c}}$ \\
\hline Gray & $0 \mathrm{Y}$ & $0,001^{\mathrm{a}}$ & $0,001^{\mathrm{c}}$ & $0,001^{\mathrm{c}}$ & $0,001^{\mathrm{c}}$ \\
\hline Matter- & Y1 & $0,018^{b}$ & $0,018^{d}$ & $0,019^{d}$ & $0,019^{d}$ \\
\hline CSF & $\mathrm{Y} 2$ & $0,001^{\mathbf{a}}$ & $0,001^{\mathrm{c}}$ & $0,001^{\mathrm{c}}$ & $0,001^{\mathrm{c}}$ \\
\hline Lesi- & OY & $0,001^{\mathbf{a}}$ & $0,001^{\mathrm{c}}$ & $0,001^{\mathrm{c}}$ & $0,001^{\mathrm{c}}$ \\
\hline Jaringan di & Y1 & $0,001^{\mathrm{a}}$ & $0,001^{\mathrm{c}}$ & $0,001^{\mathrm{c}}$ & $0,001^{\mathrm{c}}$ \\
\hline $\begin{array}{l}\text { Sekitar } \\
\text { Lesi }\end{array}$ & $\mathrm{Y} 2$ & $0,001^{\mathrm{a}}$ & $0,001^{\mathrm{c}}$ & $0,001^{\mathrm{c}}$ & $0,001^{\mathrm{c}}$ \\
\hline aternon- & 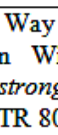 & $\begin{array}{l}\mathrm{va},{ }^{\mathrm{b}} \mathrm{Krus} \\
\mathrm{y}, 0 \mathrm{X}=\mathrm{tar} \\
\text { sat, } 0 \mathrm{Y}=\end{array}$ & $\begin{array}{l}\text { Wallis } \\
\text { fat sc } \\
700 \mathrm{n}\end{array}$ & $\begin{array}{l}\mathrm{X} 1=w \\
\mathrm{Y} 1=\mathrm{T}\end{array}$ & $\begin{array}{l}\text { Cukey, } \\
\text { fat sat, } \\
50 \mathrm{~ms} \text {, }\end{array}$ \\
\hline
\end{tabular}

Tabel 10. Hasil Uji Kappa terhadap Hasil Penilaian Responden

\begin{tabular}{cc}
\hline $\mathbf{K}$ & Keterangan \\
\hline 0,881 & Sempurna \\
\hline
\end{tabular}

Tabel 11 menunjukkan bahwa tidak terdapat perbedaan bermakna pada artefak antara kelompok tanpa fat saturation, weak fat saturation, dan strong fat saturation pada kelompok TR $700 \mathrm{~ms}(\mathrm{p}>0,05)$, TR $750 \mathrm{~ms}(\mathrm{p}>0,05)$, dan TR $800 \mathrm{~ms}$ ( $p>0,05)$. Pada semua kelompok TR, tidak terdapat perbedaan bermakna artefak antara kelompok tanpa fat saturation dan weak fat saturation $(\mathrm{p}>0,05)$ dan antara kelompok tanpa fat saturation dan strong fat saturation ( $\mathrm{p}>0,05)$, dan antara kelompok weak fat saturation dan strong fat saturation $(\mathrm{p}>0,05)$.

Tabel 12 menunjukkan bahwa tidak terdapat perbedaan bermakna pada kontras citra secara umum antara kelompok tanpa fat saturation, weak fat saturation, dan strong fat saturation pada kelompok TR $700 \mathrm{~ms}(\mathrm{p}>0,05)$, TR $750 \mathrm{~ms}$ $(p>0,05)$, dan TR $800 \mathrm{~ms}(\mathrm{p}>0,05)$. Pada semua kelompok TR tidak terdapat perbedaan bermakna artefak antara kelompok tanpa fat saturation dan weak fat saturation $(\mathrm{p}>0,05)$ dan antara kelompok tanpa fat saturation dan 
strong fat saturation ( $\mathrm{p}>0,05)$, dan antara kelompok weak fat saturation dan strong fat saturation $(\mathrm{p}>0,05)$.

Tabel 11. Hasil Analisis Bivariat Terhadap CNR pada Berbagai Jenis Fat Saturation

\begin{tabular}{|c|c|c|c|c|c|}
\hline \multirow{2}{*}{ CNR } & \multirow{2}{*}{ TR } & \multicolumn{4}{|c|}{ p value } \\
\hline & & $0 \mathrm{X}-\mathrm{X} 1-\mathrm{X} 2$ & 0X-X1 & $0 \mathrm{X}-\mathrm{X} 2$ & $\mathrm{X} 1-\mathrm{X} 2$ \\
\hline \multirow{3}{*}{$\begin{array}{l}\text { White Matter- } \\
\text { Gray Matter }\end{array}$} & $0 \mathrm{Y}$ & $0,853^{\mathrm{a}}$ & $0,843^{c}$ & $0,976^{\mathrm{c}}$ & $0,935^{\mathrm{c}}$ \\
\hline & Y1 & $0,893^{b}$ & $0,647^{d}$ & $0,877^{d}$ & $0,762^{\mathrm{d}}$ \\
\hline & Y2 & $0,853^{\mathrm{a}}$ & $0,843^{\mathrm{c}}$ & $0,976^{\mathrm{c}}$ & $0,935^{c}$ \\
\hline \multirow{3}{*}{$\begin{array}{l}\text { White Matter- } \\
\text { CSF }\end{array}$} & $0 \mathrm{Y}$ & $0,001^{\mathrm{a}}$ & $0,001^{\mathrm{c}}$ & $0,001^{\mathrm{c}}$ & $0,001^{c}$ \\
\hline & Y1 & $0,007^{b}$ & $0,017^{d}$ & $0,020^{d}$ & $0,018^{d}$ \\
\hline & Y2 & $0,001^{\mathrm{a}}$ & $0,001^{\mathrm{c}}$ & $0,001^{\mathrm{c}}$ & $0,001^{\mathrm{c}}$ \\
\hline \multirow{3}{*}{$\begin{array}{l}\text { Gray Matter- } \\
\text { CSF }\end{array}$} & $0 \mathrm{Y}$ & $0,001^{\mathrm{a}}$ & $0,001^{\mathrm{c}}$ & $0,001^{\mathrm{c}}$ & $0,001^{\mathrm{c}}$ \\
\hline & Y1 & $0,018^{b}$ & $0,018^{d}$ & $0,019^{d}$ & $0,019^{d}$ \\
\hline & Y2 & $0,001^{\mathrm{a}}$ & $0,001^{c}$ & $0,001^{\mathrm{c}}$ & $0,001^{\mathrm{c}}$ \\
\hline \multirow{3}{*}{$\begin{array}{c}\text { Lesi-Jaringan } \\
\text { di Sekitar } \\
\text { Lesi }\end{array}$} & $0 \mathrm{Y}$ & $0,001^{\mathrm{a}}$ & $0,001^{\mathrm{c}}$ & $0,001^{\mathrm{c}}$ & $0,001^{\mathrm{c}}$ \\
\hline & Y1 & $0,001^{\mathrm{a}}$ & $0,001^{\mathrm{c}}$ & $0,001^{c}$ & $0,001^{c}$ \\
\hline & Y2 & $0,001^{\mathrm{a}}$ & $0,001^{\mathrm{c}}$ & $0,001^{c}$ & $0,001^{\mathrm{c}}$ \\
\hline
\end{tabular}

Tabel 12. Hasil Analisis Bivariat Terhadap Kontras Citra Secara Umum pada Berbagai Jenis Fat Saturation

\begin{tabular}{ccccc}
\hline \multirow{2}{*}{ TR } & \multicolumn{4}{c}{ p value } \\
\cline { 2 - 5 } & $\mathbf{0 X - X 1 - X 2}$ & $\mathbf{0 X}-\mathbf{X} \mathbf{0 X}$ & $\mathbf{0 X 2}$ & $\mathbf{X 1 - X 2}$ \\
\hline 0Y & $0,400^{\mathrm{a}}$ & $0,495^{\mathrm{b}}$ & $0,186^{\mathrm{b}}$ & $0,495^{\mathrm{b}}$ \\
Y1 & $0,730^{\mathrm{a}}$ & $0,495^{\mathrm{b}}$ & $0,495^{\mathrm{b}}$ & $1,00^{\mathrm{b}}$ \\
$\mathrm{Y}^{\mathrm{b}}$ & $0,395^{\mathrm{a}}$ & $0,317^{\mathrm{b}}$ & $0,176^{\mathrm{b}}$ & $0,655^{\mathrm{b}}$ \\
\hline
\end{tabular}

Keterangan: ${ }^{a}$ Kruskal Wallis, ${ }^{\mathrm{b}}$ Mann Withney, 0X=tanpa fat sat, $\mathrm{X} 1=$ weak fat sat, $\mathrm{X} 2=$ strong fat sat, $0 \mathrm{Y}=\mathrm{TR}$ $700 \mathrm{~ms}, \mathrm{Y} 1=\mathrm{TR} 750 \mathrm{~ms}, \mathrm{Y} 2=\mathrm{TR} 800 \mathrm{~ms}$

Tabel 13. Hasil Analisis Bivariat Terhadap SNR pada Berbagai Nilai Time Repetition

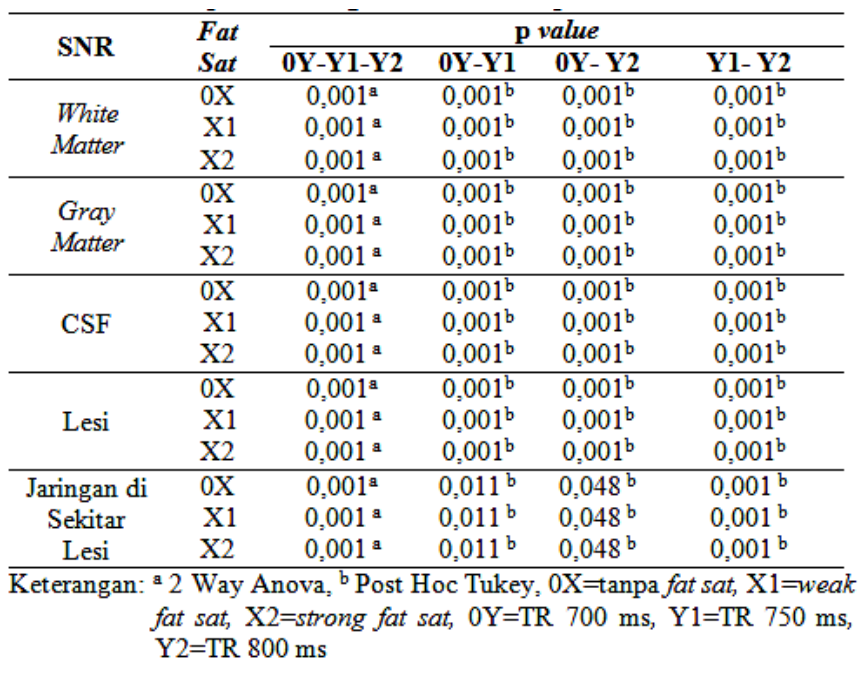

Pada semua kelompok fat saturation (tabel 13), terdapat perbedaan SNR yang bermakna antara kelompok tanpa TR $700 \mathrm{~ms}$ dan TR $750 \mathrm{~ms}(\mathrm{p}<0,05)$ dan antara kelompok TR $700 \mathrm{~ms}$ dan TR $800 \mathrm{~ms}$ ( $\mathrm{p}<0,05)$, serta antara kelompok TR $750 \mathrm{~ms}$ dan TR $800 \mathrm{~ms}(\mathrm{p}<0,05)$.
Tabel 14. Hasil Analisis Bivariat Terhadap CNR pada Berbagai Nilai TR

\begin{tabular}{|c|c|c|c|c|c|}
\hline \multirow{2}{*}{ CNR } & \multirow{2}{*}{$\begin{array}{l}\text { Fat } \\
\text { Sat }\end{array}$} & \multicolumn{4}{|c|}{ p value } \\
\hline & & 0Y-Y1-Y2 & 0Y-Y1 & 0Y-Y2 & Y1-Y2 \\
\hline White & $0 \mathrm{X}$ & $0,035^{\mathrm{a}}$ & $0,860^{\mathrm{c}}$ & $0,038^{\mathrm{c}}$ & $0,113^{\mathrm{c}}$ \\
\hline Matter- & $\mathrm{X} 1$ & $0,035^{\mathrm{a}}$ & $0,860^{\circ}$ & $0,038^{\circ}$ & $0,113^{\mathrm{c}}$ \\
\hline $\begin{array}{c}\text { Gray } \\
\text { Matter }\end{array}$ & $\mathrm{X} 2$ & $0,035^{\mathrm{a}}$ & $0,860^{\circ}$ & $0,038^{\circ}$ & $0,113^{\mathrm{c}}$ \\
\hline White & $0 \mathrm{X}$ & $0,014^{\mathrm{a}}$ & $0,001^{\mathrm{c}}$ & $0,001^{\circ}$ & $0,001^{\mathrm{c}}$ \\
\hline Matter- & $\mathrm{X} 1$ & $0,014^{\mathrm{a}}$ & $0,001^{\mathrm{c}}$ & $0,001^{\mathrm{c}}$ & $0,001^{\mathrm{c}}$ \\
\hline CSF & $\mathrm{X} 2$ & $0,014^{\mathrm{a}}$ & $0,001^{\mathrm{c}}$ & $0,001^{\mathrm{c}}$ & $0,001^{\mathrm{c}}$ \\
\hline Gray & $0 \mathrm{X}$ & $0,03^{\mathrm{a}}$ & $0,043^{\mathrm{c}}$ & $0,003^{\mathrm{c}}$ & $0,481^{\mathrm{c}}$ \\
\hline Matter- & $\mathrm{X} 1$ & $0,03^{\mathrm{a}}$ & $0,043^{\mathrm{c}}$ & $0,003^{c}$ & $0,481^{\mathrm{c}}$ \\
\hline CSF & $\mathrm{X} 2$ & $0,005^{b}$ & $0,014^{d}$ & $0,014^{d}$ & $0,021^{d}$ \\
\hline Lesi- & $0 \mathrm{X}$ & $0,035^{\mathrm{a}}$ & $0,860^{\circ}$ & $0,038^{\circ}$ & $0,113^{\circ}$ \\
\hline Jaringan & $\mathrm{X} 1$ & $0,035^{\mathrm{a}}$ & $0,860^{\circ}$ & $0,038^{\circ}$ & $0,113^{\mathrm{c}}$ \\
\hline $\begin{array}{c}\text { di Sekitar } \\
\text { Lesi }\end{array}$ & $\mathrm{X} 2$ & $0,035^{\mathrm{a}}$ & $0,860^{\circ}$ & $0,038^{\circ}$ & $0,113^{\circ}$ \\
\hline & P & is & $\begin{array}{l}\text { fat } \\
700\end{array}$ & $\begin{array}{l}\text { Post } \\
\mathrm{X} 1=\end{array}$ & \\
\hline
\end{tabular}

Tabel 15. Hasil Analisis Bivariat terhadap Kejelasan Lesi pada Berbagai Nilai TR

\begin{tabular}{ccccc}
\hline \multirow{2}{*}{ Fat Sat } & \multicolumn{4}{c}{ p value } \\
\cline { 2 - 5 } & $\mathbf{0 Y}^{-Y 1-Y 2}$ & 0Y-Y1 & 0Y-Y2 & Y1-Y2 \\
\hline 0X & $0,577^{\mathrm{a}}$ & $0,317^{\mathrm{b}}$ & $0,317^{\mathrm{b}}$ & $1,00^{\mathrm{b}}$ \\
$\mathrm{X} 1$ & $0,368^{\mathrm{a}}$ & $0,317^{\mathrm{b}}$ & $0,317^{\mathrm{b}}$ & $1,00^{\mathrm{b}}$ \\
$\mathrm{X} 2$ & $1,00^{\mathrm{a}}$ & $1,00^{\mathrm{b}}$ & $1,00^{\mathrm{b}}$ & $1,00^{\mathrm{b}}$ \\
\hline
\end{tabular}

Keterangan: ${ }^{\mathrm{a}}$ Kruskal Wallis, ${ }^{\mathrm{b}}$ Mann Withney, $0 \mathrm{X}=$ tanpa fat sat, $\mathrm{X} 1=$ weak fat sat, $\mathrm{X} 2=$ strong fat sat, $0 \mathrm{Y}=\mathrm{TR}$ $700 \mathrm{~ms}, \mathrm{Y} 1=$ TR $750 \mathrm{~ms}, \mathrm{Y} 2=\mathrm{TR} 800 \mathrm{~ms}$

Tabel 16. Hasil Analisis Bivariat terhadap Artefak pada Berbagai Nilai TR

\begin{tabular}{|c|c|c|c|c|}
\hline \multirow{2}{*}{$\begin{array}{l}\text { Fat } \\
\text { Sat }\end{array}$} & \multicolumn{4}{|c|}{ p value } \\
\hline & $0 Y-Y 1-Y 2$ & 0Y-Y1 & $0 \mathrm{Y}-\mathrm{Y} 2$ & $\begin{array}{l}\text { Y1- } \\
\text { Y2 }\end{array}$ \\
\hline $0 \mathrm{X}$ & $0,368^{\mathrm{a}}$ & $0,317^{b}$ & $1,00^{b}$ & $0,317^{b}$ \\
\hline $\mathrm{X} 1$ & $1,00^{\mathrm{a}}$ & $1,00^{b}$ & $1,00^{b}$ & $1,00^{b}$ \\
\hline $\mathrm{X} 2$ & $1,00^{\mathrm{a}}$ & $1,00^{\mathrm{b}}$ & $1,00^{b}$ & $1,00^{b}$ \\
\hline & $\begin{array}{l}\text { a }{ }^{\mathrm{a}} \text { Krusk } \\
0 \mathrm{X}=\text { tanpa } \\
\mathrm{X} 2=\text { strong } \\
750 \mathrm{~ms} \text {, Y2 }\end{array}$ & $\begin{array}{l}\text { Wallis } \\
\text { fat sat, } \\
\text { at sat, } 0 \mathrm{Y} \\
=\mathrm{TR} 800 \mathrm{r}\end{array}$ & $\begin{array}{l}\text { b Mann } \\
\text { K1=weak } \\
\text { IR } 700 \mathrm{~m}\end{array}$ & $\begin{array}{l}\text { Withney, } \\
\text { fat sat, } \\
\text { Y1=TR }\end{array}$ \\
\hline
\end{tabular}

Hasil analisis bivariat terhadap CNR white matter-gray matter, white matter-CSF, gray matter-CSF, dan lesi jaringan di sekitar lesi pada berbagai jenis nilai TR menunjukkan bahwa terdapat perbedaan bermakna pada CNR white mattergray matter ( $\mathrm{p}<0,05)$, white matter-CSF $(\mathrm{p}<0,05)$, gray matter-CSF $(\mathrm{p}<0,05)$, dan lesi-jaringan di sekitar lesi $(\mathrm{p}<0,05)$. Hasil tersebut ditunjukkan pada tabel 14 .

Pada CNR white matter-gray matter dan lesi-jaringan di sekitar lesi, terdapat perbedaan bermakna antara kelompok TR 700 ms-TR $800 \mathrm{~ms} \quad(\mathrm{p}<0,05)$, sedangkan pada kelompok TR $700 \mathrm{~ms}-$ TR $750 \mathrm{~ms}$ dan TR $750 \mathrm{~ms}$ dan $800 \mathrm{~ms}$ tidak terdapat perbedaan bermakna $(\mathrm{p}>0,05)$. Pada CNR white 
matter-CSF dan gray matter-CSF, terdapat perbedaan bermakna $(\mathrm{p}<0,05)$.

Tabel 15 menunjukkan bahwa tidak terdapat perbedaan bermakna pada kejelasan lesi antara kelompok TR 700 ms, TR $750 \mathrm{~ms}$, dan TR $800 \mathrm{~ms}$ pada kelompok tanpa fat saturation ( $\mathrm{p}$ value $<0,05$ ), weak fat saturation ( $\mathrm{p}$ value $<0,05$ ), dan strong fat saturation ( $\mathrm{p}$ value $<0,05$ ). Pada semua kelompok fat saturation tidak terdapat perbedaan bermakna CNR lesijaringan di sekitar lesi antara kelompok TR $700 \mathrm{~ms}$ dan TR $750 \mathrm{~ms}$ ( $\mathrm{p}$ value $>0,05$ ) serta antara kelompok tanpa TR 750 $\mathrm{ms}$ dan TR $800 \mathrm{~ms}$ (p value >0,05). Sedangkan antara serta antara kelompok tanpa TR $700 \mathrm{~ms}$ dan TR $800 \mathrm{~ms}$ terdapat perbedaan bermakna ( $\mathrm{p}$ value $>0,05$ ).

Tabel 16 menunjukkan bahwa tidak terdapat perbedaan bermakna pada artefak antara kelompok TR $700 \mathrm{~ms}$, TR 750 ms, dan TR 800 ms pada kelompok tanpa fat saturation ( $\mathrm{p}$ $0,05)$, weak fat saturation ( $\mathrm{p}<0,05$ ), dan strong fat saturation ( $\mathrm{p}<0,05)$. Pada semua kelompok fat saturation tidak terdapat perbedaan artefak yang bermakna, antara kelompok TR 700 ms dan TR $750 \mathrm{~ms}$ (p > 0,05), antara kelompok TR $700 \mathrm{~ms}$ dan TR $800 \mathrm{~ms}$ (p > 0,05), serta antara kelompok TR $750 \mathrm{~ms}$ dan TR $800 \mathrm{~ms}(\mathrm{p}>0,05)$.

Tabel 17. Hasil Analisis Bivariat terhadap Kontras Citra Secara Umum pada Berbagai Nilai TR

\begin{tabular}{ccccc}
\hline Fat & \multicolumn{4}{c}{ p value } \\
\cline { 2 - 5 } Sat & 0Y-Y1-Y2 & 0Y-Y1 & OY-Y2 & Y1-Y2 \\
\hline $0 \mathrm{X}$ & $0,577^{\mathrm{b}}$ & $0,317^{\mathrm{d}}$ & 0,317 & 1,00 \\
$\mathrm{X} 1$ & 0,730 & 1,00 & 0,495 & 0,495 \\
$\mathrm{X} 2$ & 0,730 & 0,400 & 0,186 & 0,495 \\
\hline
\end{tabular}

Keterangan: ${ }^{a}$ Kruskal Wallis, ${ }^{\mathrm{b}}$ Mann Withney, 0X $=\operatorname{tanpa}$ fat sat, $\mathrm{X} 1=$ weak fat sat, $\mathrm{X} 2=$ strong fat sat, $0 \mathrm{Y}=\mathrm{TR}$ $700 \mathrm{~ms}$, Y1=TR $750 \mathrm{~ms}$, Y2=TR $800 \mathrm{~ms}$

Tabel 17 menunjukkan bahwa tidak terdapat perbedaan bermakna pada artefak, antara kelompok TR 700 ms, TR 750 $\mathrm{ms}$, dan TR $800 \mathrm{~ms}$ pada kelompok tanpa fat saturation (p value > 0,05), weak fat saturation ( $\mathrm{p}$ value > 0,05), dan strong fat saturation ( $\mathrm{p}$ value $>0,05$ ). Pada semua kelompok fat saturation, tidak terdapat perbedaan artefak yang bermakna antara kelompok TR $700 \mathrm{~ms}$ dan TR $750 \mathrm{~ms}(\mathrm{p}$ value $>0,05)$ serta antara kelompok tanpa TR $750 \mathrm{~ms}$ dan TR $800 \mathrm{~ms}$ ( $\mathrm{p}$ value > 0,05). Sedangkan antara serta antara kelompok tanpa TR $700 \mathrm{~ms}$ dan TR $800 \mathrm{~ms}$ terdapat perbedaan bermakna ( $\mathrm{p}$ value $>0,05$ ).

\section{PEMBAHASAN}

\section{SNR pada berbagai Jenis Fat Saturation}

Hasil analisis bivariat terhadap nilai SNR antara kelompok tanpa fat saturation, weak fat saturation, dan strong fat saturation pada semua kelompok TR menunjukkan bahwa terdapat perbedaan bermakna pada SNR white matter ( $\mathrm{p}<0,05)$, SNR gray matter, dan SNR jaringan di sekitar lesi ( $\mathrm{p}<0,05)$. Sedangkan pada lesi dan CSF tidak terdapat perbedaan bermakna $(\mathrm{p}>0,05)$. Secara deskriptif, SNR white matter, gray matter, dan jaringan di sekitar lesi yang paling tinggi terdapat pada kelompok tanpa fat saturation, dan paling rendah terdapat pada kelompok strong fat saturation. Kecenderungan yang sama tidak ditemukan pada SNR CSF dan lesi yang menunjukkan nilai relatif sama pada kelompok tanpa fat saturation, weak fat saturation, maupun strong fat saturation.

Pada T1 WI, komponen-komponen yang mengandung lemak akan menghasilkan sinyal yang tinggi sehingga tampak terang (hiperintens). Semakin tinggi kandungan lemak, semakin tinggi intensitas sinyal yang dihasilkan. Hal ini disebabkan karena lemak memiliki $\mathrm{T} 1$ relaxation pendek sehingga recovery longitudinalnya lebih cepat dibanding komponen lainnya. Demikian halnya dengan lesi yang menyerap media kontras. Media kontras menyebabkan terjadinya pemendekan $\mathrm{T} 1$ relaxation pada lesi sehingga tampak terang pada T1 WI.

Perbedaan SNR antara kelompok tanpa fat saturation, weak fat saturation, dan strong fat saturation disebabkan karena sinyal dari komponen-komponen organ tertentu tersupresi oleh pulsa saturasi. Komponen-komponen yang mengandung lemak akan tersupresi sehingga intensitas sinyalnya berkurang. Supresi lemak pada fat saturation didasarkan pada chemical shift antara lemak dan air di bawah pengaruh medan magnet eksternal.
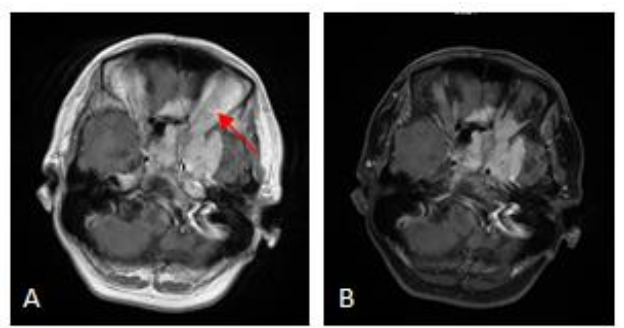

Gambar 1. Citra T1 post contrast menunjukkan lemak retro orbita (tanda panah) pada citra tanpa fat saturation (A) yang tersupresi pada citra dengan strong fat saturation (B).

Pada medan magnet 1,5 Tesla, frekuensi lemak berbeda dengan air, yaitu sebesar $217 \mathrm{~Hz}$. Pulsa saturasi hanya mempengaruhi lemak karena frekuensi Larmornya sesuai dengan frekuensi Larmor lemak. Pada MRI dengan kekuatan magnet rendah, perbedaan frekuensi tersebut semakin kecil sehingga fat saturation tidak dapat diterapkan.

Pada kelompok weak fat saturation, sinyal lemak tersupresi akan tetapi tidak sekuat pada kelompok strong fat saturation. Perbedaan tingkat supresi diperoleh dengan penggunaan spoiling gradient yang berbeda. Pada strong fat saturation, NMV lemak terdefase secara total oleh spoiling gradient, sedangkan pada weak fat saturation, NMV lemak tidak terdefase total sehingga masih menyisakan sinyal.

Semakin tinggi kandungan lemak suatu organ, semakin besar supresi yang dialami organ tersebut. White matter $20 \%$ tersusun atas phospolipid sedangkan Gray matter $9 \%$ tersusun atas phospolipid. Phospolipid adalah salah satu jenis lemak, sehingga akan tersupresi oleh pulsa saturasi. Demikian halnya dengan jaringan di sekitar lesi. Kandungan lemak pada 
jaringan di sekitar lesi beragam, tergantung pada lokasi lesi. Jaringan di sekitar lesi intra aksial, relatif lebih rendah dibandingkan jaringan di sekitar lesi ekstra aksial. Jaringan di sekitar lesi intra aksial sebagian besar berupa white matter dan gray matter, sedangkan jaringan di sekitar lesi ekstra aksial dapat berupa lapisan lemak retro orbita maupun pada jaringanjaringan lainnya

Organ-organ yang tidak mengandung lemak tidak terpengaruh oleh pulsa saturasi. Organ-organ tersebut antara lain CSF dan lesi yang menyerap media kontras. CSF sebagian besar tersusun atas air, sehingga tidak terpengaruh oleh pulsa saturasi. Penggunaan fat saturation tidak menyebabkan perubahan SNR pada lesi yang menyerap media kontras karena supresi dilakukan secara selektif terhadap komponen lemak melalui penggunan pulsa saturasi dengan frekuensi larmor tertentu. Hal ini yang membedakan fat saturation dengan teknik supresi lainnya seperti Short Tau Inversion Recovery (STIR) yang juga akan menyebabkan lesi tersupresi apabila digunakan pada citra post contrast karena supresi pada STIR didasarkan pada nilai $\mathrm{T} 1$ relaxation. Jaringan dengan $\mathrm{T} 1$ relaxation yang pendek akan ikut tersupresi, termasuk lesi yang menyerap media kontras.

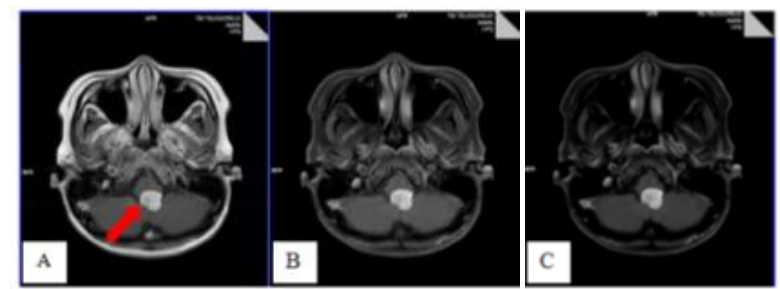

Gambar 2. Citra T1 post contrast menunjukkan enhanchement pada tumor (tanda panah), baik pada kelompok tanpa fat saturation (A), weak fat saturation (B), maupun strong fat saturation (C).

\section{CNR pada berbagai Jenis Fat Saturation}

Hasil analisis bivariat terhadap CNR antara kelompok tanpa fat saturation, weak fat saturation, dan strong fat saturation pada semua kelompok TR menunjukkan bahwa tidak terdapat bermakna pada CNR white matter-gray matter $(\mathrm{p}>0,05)$. Perbedaan bermakna ditemukan pada CNR white matter-CSF $(p<0,05)$, gray matter-CSF, $(p<0,05)$ dan lesijaringan sekitar $(\mathrm{p}<0,05)$. Secara deskriptif, CNR white matter-CSF dan gray matter-CSF yang paling tinggi terdapat pada kelompok tanpa fat saturation, dan paling rendah terdapat pada kelompok strong fat saturation. Kecenderungan berkebalikan ditemukan pada CNR lesi-jaringan sekitar lesi yang menunjukkan nilai tertinggi pada kelompok strong fat saturation dan nilai terendah pada kelompok tanpa fat saturation.

CNR dipengaruhi oleh perbedaan SNR. Hal ini disebabkan karena CNR merupakan selisih SNR antara organ satu dengan lainnya. Tidak terdapat perbedaan CNR white matter-gray matter pada berbagai jenis fat saturation disebabkan karena penggunaan fat saturation menyebabkan turunnya SNR pada white matter maupun gray matter. Kesamaan tersebut menyebabkan selisih SNR white mattergray matter tidak berubah.
Perbedaan bermakna pada CNR white matter-CSF disebabkan karena pulsa saturasi menyebabkan penurunan SNR white matter tetapi tidak menyebabkan penurunan SNR CSF sehingga selisih keduanya berbeda. Demikian halnya dengan CNR gray matter-CSF. SNR gray matter mengalami penurunan akibat penggunaan pulsa saturasi tetapi SNR CSF tetap.

Perbedaan CNR lesi-jaringan di sekitarnya diantara kelompok tanpa fat saturation, weak fat saturation, dan strong fat saturation disebabkan karena SNR lesi pada ketiga kelompok tersebut tidak berbeda, sedangkan SNR jaringan di sekitar lesi pada ketiga kelompok tersebut berbeda. SNR lesi pada kelompok strong fat saturation merupakan yang terendah diikuti kelompok weak fat saturation dan tanpa fat saturation, sehingga CNR lesi-jaringan sekitar lesi tertinggi terdapat pada kelompok strong fat saturation. Hal ini sesuai dengan Westrbrook dan Kaut ${ }^{20}$ yang menyatakan bahwa CNR dapat ditingkatkan dengan penggunaan media kontras atau dengan teknik supresi. Pemilihan teknik supresi yang tepat sangat diperlukan. Pada pemeriksaan MRI post contrast, penggunaan teknik supresi STIR justru akan mengurangi informasi citra, karena gambaran lesi yang menyerap media kontras akan ikut tersupresi.

CNR white matter-CSF, gray matter-CSF, dan lesijaringan di sekitar lesi akan semakin tinggi apabila pulsa saturasi yang digunakan semakin kuat. Hal ini disebabkan karena semakin kuat pulsa saturasi, semakin besar selisih SNR di antara organ-organ tersebut.

\section{Kejelasan Lesi pada berbagai Jenis Fat Saturation}

Hasil analisis bivariat menunjukkan bahwa terdapat perbedaan bermakna pada kejelasan lesi antara kelompok tanpa fat saturation, weak fat saturation, dan strong fat saturation pada semua nilai TR ( $\mathrm{p}<0,05)$. Diantara kelompok tanpa fat saturation dengan weak fat saturation dan diantara kelompok tanpa fat saturation dengan strong fat saturation, diketahui adanya perbedaan bermakna ( $\mathrm{p}>0,05)$. Akan tetapi diantara kelompok weak fat saturation dan strong fat saturation tidak terdapat perbedaan bermakna ( $\mathrm{p}>0,05)$. Secara deskriptif, rerata hasil penilaian responden terhadap kejelasan lesi lebih tinggi pada kelompok strong fat saturation dan hampir sama kelompok weak fat saturation sedangkan pada kelompok tanpa fat saturation cenderung lebih rendah.

Penjelasan terhadap hasil tersebut adalah karena adanya pulsa saturasi yang mensupresi sinyal jaringan di sekitar lesi sehingga gambaran lesi tampak lebih jelas pada kelompok strong fat saturation dan weak fat saturation. Akan tetapi, perbedaan kejelasan lesi diantara strong fat saturation dan weak fat saturation tidak teramati oleh kedua responden meskipun secara pengukuran kuantitatif terdapat perbedaan CNR pada kedua kelompok tersebut.

Kejelasan lesi pada citra T1 WI post contrast sangat penting bagi keberhasilan terapi tumor otak. Citra T1WI post contrast memberikan gambaran batasan tumor dan merupakan dasar untuk menentukan Region of Interest (ROI) pada pembuatan citra perfusi. Dengan batasan tumor yang tegas, diharapkan dapat dilakukan terapi dengan tuntas tanpa terlalu banyak merusak jaringan sehat di sekitarnya mengingat 
jaringan otak memiliki peran yang vital dan tidak dapat diperbaharui.

\section{Artefak pada berbagai Jenis Fat Saturation}

Tidak adanya perbedaan bermakna pada artefak tampak dari hasil uji bivariat yang menunjukkan ( $\mathrm{p}>0,05)$ antara kelompok tanpa fat saturation, weak fat saturation, dan strong fat saturation pada semua nilai TR. Diantara kelompok tanpa fat saturation dengan weak fat saturation, kelompok tanpa fat saturation dengan strong fat saturation, dan kelompok weak fat saturation dan strong fat saturation diketahui bahwa tidak ada perbedaan bermakna ( $p>0,05)$. Secara deskriptif, hasil penilaian responden terhadap artefak pada kelompok adalah tidak tampak.

Hal ini dapat dipahami karena pada semua kelompok, scan time yang relatif cepat, yaitu 2-3 menit. Scan time pada sekuen T1 WI memang relatif lebih cepat dibanding dengan sekuen T2 WI karena nilai TR yang digunakan relatif pendek yaitu 400-800 ms. Dengan scan time yang cepat, timbulnya motion artifact yang dapat dicegah.

\section{Kontras Citra Secara Umum pada berbagai Jenis Fat Saturation}

Berdasarkan hasil analisis bivariat, diketahui bahwa tidak terdapat perbedaan bermakna pada kontras citra secara umum ( $\mathrm{p}>0,05)$ antara kelompok tanpa fat saturation, weak fat saturation, dan strong fat saturation pada semua nilai TR. Diantara kelompok tanpa fat saturation dengan weak fat saturation, kelompok tanpa fat saturation dengan strong fat saturation, dan kelompok weak fat saturation dan strong fat saturation diketahui bahwa tidak ada perbedaan bermakna ( $\mathrm{p}$ 0,05). Secara deskriptif, responden memberikan penilaian "baik" terhadap kontras citra secara umum pada kelompok.

Hal ini disebabkan karena kontras secara umum dinilai dari perbedaan kontras white matter-gray matter. Kontras white matter-gray matter tidak berbeda pada kelompok tanpa fat saturation, weak fat saturation, dan strong fat saturation, sesuai dengan hasil pengukuran secara kuantitatif pada CNR white matter-gray mater yang menunjukkan bahwa tidak ada perbedaan bermakna $(\mathrm{p}<0,05)$.

\section{SNR pada berbagai Nilai TR}

Hasil analisis bivariat terhadap nilai SNR antara kelompok TR $700 \mathrm{~ms}$, TR $750 \mathrm{~ms}$, dan TR $800 \mathrm{~ms}$ pada semua kelompok fat saturation menunjukkan bahwa terdapat perbedaan bermakna pada SNR white matter $(\mathrm{p}<0,05)$, SNR gray matter, SNR CSF ( $p<0,05)$, SNR lesi $(\mathrm{p}<0,05)$, dan SNR jaringan di sekitar lesi $(\mathrm{p}<0,05)$. Secara deskriptif, SNR white matter, gray matter, CSF, lesi, dan jaringan di sekitar lesi yang paling tinggi terdapat pada kelompok TR $800 \mathrm{ms,}$ dan paling rendah terdapat pada kelompok TR $700 \mathrm{~ms}$.

Hal tersebut dapat dipahami karena semakin tinggi nilai TR, semakin besar longitudinal recovery yang terjadi sehingga semakin banyak magnetisasi yang dapat digunakan untuk akuisisi berikutnya. Pada penggunaan fat saturation, diperlukan nilai TR minimal yang lebih panjang karena adanya aplikasi pulsa saturasi $90^{\circ}$ sebelum aplikasi pulsa standar. TR minimal adalah $700 \mathrm{~ms}$.

Pemilihan nilai TR harus dilakukan dengan hati-hati karena akan berpengaruh pada kontras citra (pembobotan). Pada T1 WI, nilai TR diatur pendek agar jaringan-jaringan dengan $\mathrm{T} 1$ relaxation pendek dapat mencapai recovery total pada saat dilakukan readout sehingga tampak terang. Penggunaan TR yang terlalu panjang dapat menyebabkan jaringan-jaringan dengan $\mathrm{T} 1$ relaxation panjang juga mengalami recovery total sehingga tidak dapat diperoleh citra dengan pembobotan T1. TR yang terlalu panjang juga dapat meningkatkan scan time yang juga dapat meningkatkan potensi timbulnya artefak akibat pergerakan pasien. Semakin panjang TR akan meningkatkan nilai SNR, mengurangi pembobotan $\mathrm{T} 1$ dan meningkatkan scan time. Untuk mendapatkan pembobotan T1, nilai TR diatur pada rentang $400 \mathrm{~ms}-800 \mathrm{~ms}$.

\section{CNR pada berbagai Nilai TR}

Hasil analisis bivariat terhadap nilai CNR antara kelompok TR $700 \mathrm{~ms}$, TR $750 \mathrm{~ms}$, dan TR $800 \mathrm{~ms}$ pada semua kelompok fat saturation menunjukkan bahwa terdapat perbedaan bermakna pada CNR white matter-gray matter $(\mathrm{p}<$ $0,05), \mathrm{CNR}$ white matter-CSF( $\mathrm{p}<0,05)$, CNR gray matterCSF $(p<0,05)$, CNR lesi-jaringan sekitar lesi $(\mathrm{p}<0,05)$. Perbedaan $\mathrm{CNR}$ disebabkan karena perbedaan $\mathrm{T} 1$ relaxation time antara komponen satu dengan lainnya. CNR akan semakin tinggi apabila perbedaan tersebut semakin besar.

Secara deskriptif, CNR paling tinggi terdapat pada kelompok TR $700 \mathrm{~ms}$, dan paling rendah terdapat pada kelompok TR $800 \mathrm{~ms}$. Hal ini terlihat pada CNR white mattergray matter dan CNR white matter-CSF. Hal ini disebabkan karena adanya perbedaan $\mathrm{T} 1$ relaxation time antara kedua organ. Semakin panjang TR, perbedaan tersebut akan semakin kecil sehingga selisih nilai SNR diantara keduanya menjadi lebih kecil.

\section{Kejelasan Lesi pada berbagai Nilai TR}

Hasil analisis bivariat terhadap nilai kejelasan lesi antara kelompok TR $700 \mathrm{~ms}$, TR $750 \mathrm{~ms}$, dan TR $800 \mathrm{~ms}$ pada semua kelompok fat saturation menunjukkan bahwa terdapat perbedaan bermakna pada kejelasan lesi (p value >0,05). Hal ini disebabkan karena penglihatan responden tidak mampu membedakan tingkat kejelasan lesi pada rentang TR yang berdekatan. Sistem komputer pada pesawat MRI mampu membedakan hasil pengukuran kuantitatif pada SNR dan CNR, akan tetapi mata manusia mempunyai keterbatasan dalam membedakan perbedaan SNR tersebut.

\section{Artefak pada berbagai Nilai TR}

Tidak adanya perbedaan bermakna pada artefak tampak dari hasil uji bivariat yang menunjukkan $(\mathrm{p}>0,05)$ antara kelompok TR $700 \mathrm{~ms}, 750 \mathrm{~ms}$, dan $800 \mathrm{~ms}$ pada semua jenis fat saturation. Tidak ada perbedaan bermakna diantara kelompok TR $700 \mathrm{~ms}$ dengan TR $750 \mathrm{~ms}$, TR $700 \mathrm{~ms}$ dengan TR $800 \mathrm{~ms}$, serta TR $750 \mathrm{~ms}$ dan $800 \mathrm{~ms}$ diketahui bahwa (p > $0,05)$. Secara deskriptif, hasil penilaian responden terhadap artefak pada kelompok adalah tidak tampak. 
Hal ini dapat dipahami karena pada semua kelompok, scan time yang relatif cepat, yaitu 2-3 menit. Scan time pada sekuen T1 WI memang relatif lebih cepat dibanding dengan sekuen T2 WI karena nilai TR yang digunakan relatif pendek yaitu 400-800 ms. Dengan scan time yang cepat, timbulnya motion artifact yang dapat dicegah.

\section{Kontras Citra Secara Umum pada berbagai Nilai TR}

Berdasarkan hasil analisis bivariat, diketahui bahwa tidak terdapat perbedaan bermakna pada kontras citra secara umum (p > 0,05) antara kelompok TR 700 ms, 750 ms, dan $800 \mathrm{~ms}$ pada semua jenis fat saturation. Diantara kelompok tanpa fat saturation dengan weak fat saturation, kelompok tanpa fat saturation dengan strong fat saturation, dan kelompok weak fat saturation dan strong fat saturation diketahui bahwa tidak ada perbedaan bermakna ( $p>0,05)$. Secara deskriptif, hasil penilaian responden terhadap kontras citra secara umum pada kelompok adalah tinggi. Tidak ada perbedaan bermakna diantara kelompok TR 700 ms dengan TR $750 \mathrm{~ms}$, TR $700 \mathrm{~ms}$ dengan TR $800 \mathrm{~ms}$, serta TR $750 \mathrm{~ms}$ dan 800 ms diketahui bahwa $(\mathrm{p}>0,05)$.

Hal ini disebabkan karena kontras secara umum dinilai dari perbedaan kontras white matter-gray matter yang tidak berbeda pada kelompok tanpa fat saturation, weak fat saturation, dan strong fat saturation. Hal tersebut didukung hasil pengukuran secara kuantitatif pada CNR white mattergray mater yang menunjukkan bahwa tidak ada perbedaan bermakna $(\mathrm{p}<0,05)$.

\section{Kombinasi Jenis Fat Saturation dan Nilai TR yang dapat menghasilkan Informasi Citra Paling Optimal}

Pemilihan kombinasi jenis fat saturation dan nilai time repetition yang paling optimal dalam menghasilkan citra $\mathrm{T} 1$ WI post contrast dilakukan dengan pertimbangan beberapa hal, yaitu kemampuan citra dalam menampakkan lesi dan scan time.

Pada berbagai jenis fat saturation, kelompok tanpa fat saturation menghasilkan nilai SNR yang paling tinggi pada semua objek. Sedangkan apabila ditinjau dari segi CNR lesijaringan di sekitar lesi, kelompok strong fat saturation dengan menghasilkan nilai tertinggi. Demikian halnya dengan penilaian kejelasan lesi oleh radiolog. Hasil penilaian terhadap artefak dan kontras citra secara umum pada semua kelompok menunjukkan nilai yang sama.

Pada berbagai nilai time repetition, kelompok TR 800 ms menghasilkan nilai SNR yang paling tinggi pada semua objek. Demikian halnya apabila ditinjau dari segi CNR lesijaringan di sekitar lesi. Akan tetapi hasil penilaian radiolog terhadap kejelasan lesi, artefak, dan kontras citra secara umum menunjukkan nilai yang sama pada semua nilai TR.

Scan time pada tanpa fat saturation merupakan yang paling singkat diikuti kelompok weak fat saturation dan strong fat saturation. Pada berbagai nilai time repetition, TR $700 \mathrm{~ms}$ memerlukan scan time yang paling singkat, diikuti kelompok TR $750 \mathrm{~ms}$, dan TR $800 \mathrm{~ms}$.

Kombinasi strong fat saturation dan TR $700 \mathrm{~ms}$ merupakan yang paling optimal. Dengan strong fat saturation, dapat diperoleh kejelasan lesi dan nilai CNR lesi-jaringan di sekitar lesi yang paling tinggi. SNR yang dihasilkan dengan TR $700 \mathrm{~ms}$ relatif lebih rendah, tetapi hal tersebut tidak mempengaruhi penilaian radiolog terhadap kejelasan lesi, artefak, maupun kontras citra secara umum. Dengan TR 700 $\mathrm{ms}$, scan time menjadi lebih singkat, sehingga meminimalkan terjadinya artefak. Dalam penelitian ini, perbedaan scan time relatif tidak signifikan, tetapi apabila diterapkan pada pemeriksaan yang terdiri dari tiga irisan (aksial, koronal, dan sagital) akan terlihat beda yang signifikan. Penggunaan TR $700 \mathrm{~ms}$ diharapkan dapat menjadi kompensasi bagi adanya tambahan scan time akibat penggunaan strong fat saturation.

\section{SIMPULAN}

Terdapat perbedaan SNR (white matter, gray matter, lesi, dan jaringan di sekitar lesi), CNR (white matter-CSF, gray matter-CSF, dan lesi-jaringan di sekitar lesi), serta kejelasan lesi Citra T1 WI post contrast MRI brain dengan kasus tumor antara kelompok tanpa fat saturation, weak fat saturation, dan strong fat saturation.

Terdapat perbedaan SNR (white matter, gray matter, CSF, lesi, dan jaringan di sekitar lesi), CNR (white matterCSF, gray matter-CSF, dan lesi-jaringan di sekitar lesi) Citra T1 WI post contrast MRI brain dengan kasus tumor antara kelompok tanpa TR $700 \mathrm{~ms}$, TR $750 \mathrm{~ms}$, dan TR $800 \mathrm{~ms}$. Kombinasi strong fat saturation dengan nilai TR $700 \mathrm{~ms}$ dinilai mampu menghasilkan Citra T1WI post contrast pada MRI brain dengan kasus tumor yang paling optimal.

\section{DAFTAR PUSTAKA}

American Brain Tumour Association. 2008. A Primer of Brain Tumors A Patient's Reference Manual, 8th Edition. American Brain Tumour Association.

Bernstein, MA; King, KF, and Zhou, XJ. 2004. MRI Pulse Sequence. USA. Elsevier.p.305-345

Jemal A, Thomas A, Murray T, and Samuels A. Cancer Statistics. 2003. CA: A Cancer Journal for Clinicians. American Cancer Society. p.53-1; 5-26.

Mehndiratta A and Giesel FL. 2011. Brain Tumour Imaging. In: Diagnostic Techniques and Surgical Management of Brain Tumors, Abujamra AL. ed. Available from:http://www.intechopen.com/books/diagnostictechniques-and-surgical-management-of-braintumors/ brain-tumour-imaging

Chysikopoulus HS. 2009. Clinical MRI Imaging and Physics: a Tutorial. Berlin; Springer.

Westbrook C. 1999. Handbook of MRI Technique. LTD. London. Blackwell Science.p.79-125

Woodward P and Freinmarck, R. 1995. MRI for Technologist. New York. McGraw-Hill Inc. p. 59-73

Zhou ZR, Shen, Tian-Zhen C, Xing-rong, and Peng WJ. 2006. Diagnostic value of contrast-enhanced fluid-attenuated inversion-recovery MRI for intracranial tumors in comparison with post-contrast T1W spin-echo MRI. Chinese Medical Journal; p.110. 